in the neighbourhood of Foochow, and hundreds of natives may be seen buthing there daily, and, as far as can be learned from several intelligent Chinese, with benefit. Hepatic disease is common amongst the foreign resilents, owing not only to unnecessary exposure to the sun, but to high living, in a climate and at a time when much muscular exercise cannot be taken. Abscess is the common result; frequently a broken-up constitution, and the necessity of a voyage home. Brain affections are common: they do not stand general bleeding; the local abstraction of blood, cold applications to the shaved head, the cold douche, purgatives, with the free administration of calomel, being most successful. Typhoid fever is likewise common at Foochow, while catarrhs of a mild nature are occasionally met with in the spring, and are easily treated. Tho prevailing disease of Hong.Kong is a fever combining the cha. racter of the African and West Indian fevers; it is endemic, and may be assumed to be the fixed malady of the island. This part of the suliject has recently been most ably treated by Dr. Smart, Deputy Inspector-Geveral R.N., in a valuable paper read before the Epidemiolouical Society.

The use of river water for drinking is prejudicial to health, and is one cause of the dysentery and intestinal worms which have been so prevalent in our ships and in the mercantile marine. When the writer was stationed at Shanghai, he recommended filterel water (to be purchased on shore), the expense being one dollar per tun, but this suggestion was not complied with on economical grounds. Besides, in steamers, we have the means of condensing good and pure water, and to compel men to drink river water on account of the expense of fuel is, to say the least of it, most unwise and injudicious parsimony. * "When the waters are mudly in rivers," says Dr. Saunders, " and no oiher water is to be had for drinking, alum should be added to it in the proportion of about one ounce to a tun: it makes it elear and pure, and acts beneficially on the system at the same time by cooling the body and bracing up its relaxed fibres. It is also a point of vast importance to be understood, that organic matters in solution pass through filters except they are removed by chemical action."

There can be little doubt that the chief offenoing cause exists "in infusorial animalcules of a poisonous nature, or in the form of minute organic germs of the animal and vegetable world, called into action by the great heat of the rivers (sellom under $88^{\circ}$ in the hot season), and perhaps fostered and increased by the rich and putrid manures used by the Chinese, and the disorganized matter produced by the decay of rice crops." + Besides, the water at the anchorages of Shanghai and Foochow are rendered still more imnure by the sewers from the city, and from the immense fleet of shius and junks. "On the other hand," as Dr. Bryson remurks, "there were vessels in which distilled water had been used exclusively for nearly two years, still the surgeon reports that nearly one-half the patients who had been ill of fever vomited oucusionally one, two, or three worms at a time; they were mist frequently observed during the months of June and July, when the men were in the habit of eating largely of the fruit called lycheese, in which the germ of the parasite is supposed by the Chinese to exist."

It may be mentioned as an interesting fact that the Chinese are acquainted with the power of arsenic in checking the return of ague. The following is a translation of a Chinese pre. scription for arue, for which I am indebted to Wm. Lockhart, Esq., F.R.C.S.: "Take one dried orange; sulphuret of arsenic, three drachms: scoop out the inside of the orange, introduce the arsenic into it, and orer a slow fire let them be roasted to ashes, preserving the essence of both; then reduce the whole to powder, and of this let each dose be three drachms, taken with old or nellow wine." According to this mode of pre paration the dose of arsenic must be very uncertain, for as the sulphuret is volatile a large portion of it will pass off; but some of the metal, in the form of oxile, will remain among the ashes of the orange, quite suffecent for a powerful dose. I may add that the Chin se use calomel ointment in cases of sloughing alcer, with the view of cleausing the sore and producing a free purulent discharge.

During the recent operations in China, the casualties in our attacking force and in that of onr French allies were occasioned by round and grape shot, gingall balls and slugs of lead and iron, and bows and arrows. besides, several deaths and severe

* In aldition to the sanitary sugrestions I have already ventured to make, I most strongly recommend picserved pistatoes to be issucd at least twice a week to ships' companies in all ressels proceeding to Chma, and on other lon voyages. This would be a very desirable addition to the usual diet at sea and the expense would not be great.

+ Medical and Surgical Hints, p. 19.

Statistical Report, East india and China Station (1337-1813), p. 89.
\$ Medical Statistical Returns (1853), p. 135 . burns were occasionell by the explosion of a powder magazine at the forts on the Peiho river. 'The bullets and slugs were of a very irregular shape, and in many cases sharp and angular, although some were rounded and cast, like our own musketballs. The soft parts were much lacerated and contused, but in many cases life was saved by the bad construction of the firearms, and the want of propelling power in the powder used by the Chinese.

P.S.-Regarding my remarks on the use of river-water in China, I believe that, chiefly in consequence of the remonstrances of medical officers, an Admiralty order has at length been issued enjoining the use of condensed water in China, and in other cases when good and pure water cannot be obtained. Those only who have served in the rivers of China can fully appreciate the importance of this very obvious and necessary sanitary precaution. This leads me to allude to another point of naval hygiene. The decks of ships, and even the ward-room and gun-room, are almost invariably saturated with water every day in all weathers, with the very laudable view of obtaining spotless whiteness of the decks, and both officers and men have frequently to breathe a humid and debilitating atmosphere far from conducive to health, much less favourable for the treatment of disease. The statistical reports of the navy, and the remarkable cases of the Vernon and Eagle on the South Ame. rican station, prove beyond all doubt that the practice alluded to is fraught with mischief, tending, as it does, to reduce physical force, co-operating in the inducrion of diseases of debility, and rendering the borly more susceptible of the attacks of vio. lent disease. If in certain states of the weather dry rubbing were substituted, especially on the lower decks, I believe the present high average health of the naval service would be still further increased.

This being the age of sanitary reform, I may be allowed to make one or two other suggestions. Notwithstanding the reconstruction of the navy, there must still be some vessels com. posed at least partially of wood. I therefore recommend the bil res to be covered with a thin metallic coating of copper or galvanized zine (Munt $z$ ' metal). It wonld facilitate the cleaning of the bilges, preserve the wood, prevent the absorption of grease, and diminish the evolution of noxions gases. In warm. climates the smell of bilge is sometimes intolerable, and if not one of the exciting causes of fever, at all events leads to great annoyance and discomfort. This is no merely theoretical scheme, but it has received the sanction of several practical men whom $I$ have consulted on the subject. In steamers of the navy the number of stokers in tropical climates is too small. In some vessels the temperature of the stoke-hold is as high as $138^{\circ}$, and the average, $115^{\circ}$ during summer. Under these circumstances, the men are sometimes unable to work from absolute exhaustion, and should be allowed more rest than the present limited number admits. It would be of advantage to euter some of the natives of India and China for this service when Her Majesty's ships are employed on that station. Exposure to the sun is a fruitful source of disease, and on board ship the awnungs are frequently too thin, allowing the rays of the sun to venetrate. A double awning, when the ship remains at anchor during the extreme heat of summer, would undoubtedly be advantartous in a sanitary point of view. I have only to add, that in almost every par' of China the hottest months of the year are July and Angust. In the north, the heat is very oppressive from the middle of June to the middle of September. In the Gulf of Pecheli heavy and continuous rains fiequently fall in June, and the air is surcharged with electricity, sheet and forked lightning being very prevalent. About Canton the winters are much warmer than they are at the more northern ports; the thermometer seldom falls to the freezing point, and ice and snow are of rare occurrence. In the month of December a temperature of $45^{\circ} \mathrm{feels}$ cold after the excessive heat of the summer and autumn. The island of Chusan would be an excellent situation for the head-quarters of our naval and military forces in China. They are likely to suffer less here from the effects of climate than anywhere else, and an abundant supply of fresh provisions can be procured.

Kiulerminster, 1862 .

\section{ON AN UNUSUAL CASE OF LITHOTOMY.} BY R. W. WAUDBY GRIFFIN, M.D. ST. AND.

Gronge $H \longrightarrow$, a fine, fat, healthy-looking boy, aged three years and a half, residing at Fremantle, came to the Dispensary with symptoms of stone in the bladder. On sounding him I found one. Some unhealthy symptoms being present, I de- 
layed the operation for three weeks, and was arranging with other meilical men to operate on Tuesday, April $29 \mathrm{rb}$, when on the preceding Sunday evening I was sent for, as the child had not passed his urine since the Friday night. I found the child writhing with pain, and the scrotum somewhat swollen and red. I passed a catheter, and while doing so felu it touch the stone, whish it gently pushed back into the bladder, the stone being partially impacted in the last part of the urethra. Two or three drops of purulent looking fluid first passed through the catheter, followed immediately by the urine. The boy appearing so well after his urine had been drawn off, and the scrotum not being much swollen, which swelling I considered due to clema, and not to urinous extravasation, I simply ordered bran fomentations to the parts.

Next day the boy seemed pretty well, the swelling and slight redness of the scrotum having entirely disappeared. Four or five days after this, I noticed a small lump an inch and 2 half above the pubis, which remained stationary until the twelf th day after the retention, when, being anxious to ope rate, I asked Dr. Lake to see the case with me. On grasping the hardness and moving the centre with two fingers, there was perceived a doubtful sensation of fluctuation. We con. cluded it would be better to wait a day or two, as then most probably it would be evident whether the hardness was an abscess. I told the mother to bring the child to my house in two days, or before if anything unusual happened.

The next night but one (May 9th) I was sent for, as the child could not micturate, and was much swollen. I found the scrotum, penis, and lower part of the abciomen livid and greatly swollen. 1 passed a catheter, but succeeded in drawing off only a small quantity of urine. I then made an incision over the seat of the hardness abont an inch in depth, when out welled a good-sized cupful of urine, followed by a drachm or two of pus, after which the urine continued to dribble from the wound. The parts were well fomented with bran poultices, a linseed meal one being placed over the wound.

On the morrow Dr. Sims kindly put the boy under chloroform, when a director and probe, with a slight elevation of the handle, and passed a little downwards and then backwards into the bladder through the incision I had marle on the previous night, could easily be made to touch the stone. The child passed urine in full streams both by the wound and the urathra. He appcared tolerably well, and the swollen parts had nearly attained their normal size. I decided to perform the high operation for the removal of the stone on the next morning.

With the kind assistance of Drs. Lake, Aldridge, Sims, and Mr. Trend, the child on May 11 th having been placed under the influence of chloroform. I passed a probe through the incision into, as I thought, the bladder-the urine at the time freely passing through the wound - and then commenced cutting on the probe towards the pubis. After cutring down a little way I found the probe passed just in front instead of behind the pubis through an opening into the urethra. (The parts were very fat and fleshy.) Not being able, after several attempts, to pass the probe into the bladder, as was easily done the day before, I was compelled to desist and commence the lateral operation.

The child was at once put into the ordinary lithotomy position and a staff passed, with which we could not feel the stone, but thought nothing of that, as the bladder was empty, and the stone had been felt just before commencing the first opera tion. After cutting through the skin and fascia, and breaking away the tissues, the groove in the staff was at once felt and an incision made on it. $M y$ finger easily passed on and went round the end of the staff, which bad passed out through the opening in the urethra into the cellular tissue between the bladder and rectum. The staff was withdrawn, and with a little difficulty introduced into the bladder; the stone, however, was not felt. A slight incision on the groove was again made, and my finger worked into the bladder, when 1 drectly felt the stone. The staff was withdrawn, a scoop passed into the wound, and the stone brought away between my finger and the scoop. The stone is about the size and shape of a sparrow's egg, and composad of phosphate of lime. Throughout the operation the child did not lose a drachm of blood. No dressings were applied to the wounds; a napkin was pinned on. Ten minims of tincture of opium were given, and five ordered to be taken every two hours. He passed the rest of that day under the influence of laudanum.

On the morrow, when entering the bouse about seven A. $\mathbf{M}_{0}$, I saw the child's lips and tongue quivering, and in about a minute he became thoronghly convulsed. He was quite narcotised at the time, but was brought-to by briskly slapping his face with a wet towel; afterwards I had cold wet rags applied to his head. He had more or less muscular quivering during the day. (The mother had given the one drachm of tincture of opium in eight hours, which, with the irritation of the wounds, might bave had something to do with the convulsion His pulse was 160 ; tongue very dry and brown; urine passed through both wounds.

On the following day he was much better; the urine passed by the urethra. A poultice was placed on the upper wound. On the next day the urine ceased to come through the lower wound. After this, with the exception of a high pulse, he continued looking as if nothing was the matter, eating heartily of almost anything nutritious and wholesome he could obtain, passing his urine in a full stream from both the upper wound and the urethra, and taking small doses of bicarbonate of potass and tincture of hyoscyamus until the 20 th, when a rag spread with cerate was substitutel for the poultice to the upper wound. An attempt was then made to keep a catheter in the bladder, so that the npper wound might heal; but the young rascal was so well, so strong, and so uiruly, that it was quite impossible to keep anything in the urethra. The stream of urine which passed through the upper wound continued, however, to get smaller, and on the morning of the 28 th it flowed through this channel for the last time, but he complained of pain when micturating. On the 3 lst this pain had ceased, and he walked to my house, a distance of a mile, perfectly well.

On the twelfth day after the operation I ordered him to be taken out in a perambulator.

June 2rd, 1862 .

\section{A MONOCULOUS MALE FCEUS.}

\section{By JOHN SCOTT, Esq., L.R.C.S. EdIN., West Maitland.}

THE subject of this monstrosity was born on July $1 s^{2}, 1860$. and lived four hours. Immediately after the birth my attention was directed to a large, puffy swelling on the forehead, below which was a fissure. On examining closely and opening the fissure, a perfect eye was disclosed in the centre; the pupil followed the light, and the child evi. dently saw all around it, crying lustily. The photograph, from which the accompanying engraving was drawn, was not taken till next day (the child having been born on Sunday), and then the frontal tumour had receded, leaving a depression. The two orbital arches are thrown into one; and both that and the depression are well shown. No ves. tige of a nose was perceptib!e; but there was a slight fissure immediately below the eye, about three eighths of an inch in depth. Neither anterior nor posterior fontanelle existed, the deficiency of the frontal bone forming the substitute. The child was otherwise well-formed in every respect, the shrunken appear. ance being owing to my having disembowelled it for preservation. The father and mother have six other chil. dren, all healthy. Both parents are below the average size, and of highly nervous temperament - the mother hysterical.

I cannot assign any cause for the monstrosity, except that shortly after conception the mother saw a child on whom I had operated for hare-lip, leaving a mark which the fissure below the eye closely resembles; and also that she had been much with a friend whose child had a cleft palate, and, after having lingered for many months in a state of marasmus, ultimately died not long before the birth of my lusus. It is at present at Sydney, having been

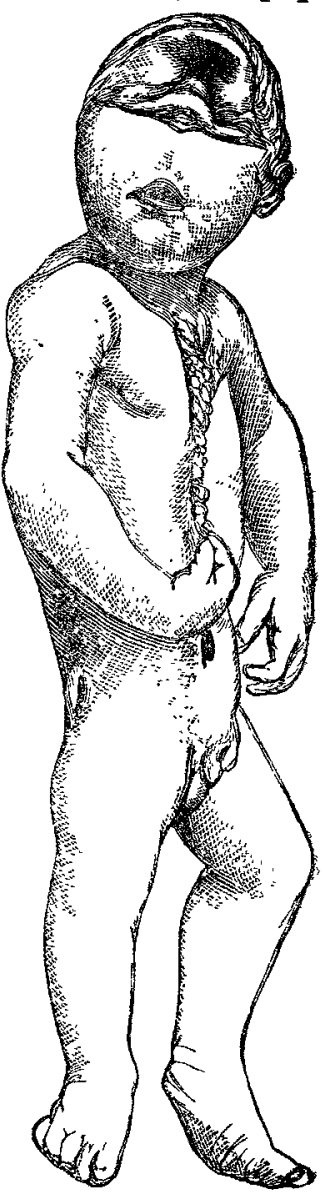
sent there for exhibition before the Medical Association.

Dr. Wilke, of Dublin, has, I believe, written a monograph on the subject; but this ease appears to me so peculiar that it may deserve a place in the pages of THE LANCET.

West Maitland, New South Wales, 1861. 